Serhii Mikhailovich Levoniuk,

Researcher, Ukrainian Scientific Research Institute for Natural Gases,

20 Himnasiyna Emb., Kharkiv, 61010, Ukraine,

e-mail: sergii.levonyuk@gmail.com, https://orcid.org/0000-0002-4073-8152;

Vitaliy Viktorovich Samoilov,

$\mathrm{PhD}$ (Geology), Head of the Department, Ukrainian Scientific Research Institute for Natural Gases, e-mail: samoilov_gas@ ukr.net, https://orcid.org/0000-0002-0650-2808;

Igor Valerijovich Udalov,

Doctor of Sciences (Geology), Associate Professor, Head of the Department of Hydrogeology,

V. N. Karazin Kharkiv National University, 4 Svobody Sq., Kharkiv, 61022, Ukraine, e-mail: igorudalov8@gmail.com, https://orcid.org/0000-0003-3844-6481;

Viacheslav Oleksijovich Petik,

$\mathrm{PhD}$ (Technics), Senior Lecturer, Department of Hydrogeology,

V.N. Karazin Kharkiv National University, e-mail: nemuk1310@gmail.com, https://orcid.org/0000-0002-4055-0926

\title{
ECOLOGICAL AND HYDROGEOLOGICAL FACTORS OF QUALITATIVE COMPOSITION DESTABILIZATION OF DRINKING GROUNDWATER WITHIN THE CENTRAL PART OF DDAB
}

С. М. Левонюк, В. В. Самойлов, І. В. Удалов, В. О. Петік. ЕКОЛОГО-ГІДРОГЕОЛОГІЧНІ ФАКТОРИ ДЕСТАБІЛІЗАИЇ ЯКІСНОГО СКЛАДУ ПИТНИХ ПІДЗЕМНИХ ВОД ЦЕНТРАЛЬНОЇ ЧАСТИНИ ДДАБ. Робота прИсвячується актуальній екологічній темі - дослідженню дестабілізачії якості питних підземних вод в умовах сучасного інтенсивного техногенезу геологічного середовища. Авторами обтрунтовані 2 складові даної проблеми: встановлення екологогідрогеологічних факторів впливу на якісний склад вод та обтрунтування екологічно безпечного використання иџих вод.

На базі раціонального комплексування геологічних, еколого-гідрогеологічних і неотектонічних умов території робіт виявлені фактори впливу на якісний склад підземних вод на бучаџько-канівських водозаборах. Завдяки иьому - запропоновані пріоритетні показники якості ичих вод для гідрогеохімічного моніторингу в умовах інфільтрачії забруднюючих речовин $з$ поверхні та їх підтоку знизу в зонах впливу тектонічних структур. Встановлений зв язок факторів впливу із якісним складом дозволив розробити еколого-гідрогеологічний підхід до екологічно безпечного використання вод иільового комплексу у межах Східної Украӥни. Весь комплекс виконаних досліджень апробовано на мережі водозаборів Полтавської міської агломераиії. Встановлено рівні забруднення підземних вод та обтрунтовано оптимальний загальний водовідбір на водозаборах міста. Виявлено і кількісно оцінено прямий позитивний зв'язок зміни вмісту характерних елементів-індикаторів впливу на еколого-гідрогеологічний стан підземних вод від величини водовідбору в зоні безпосереднього впливу тектонічних порушень Східно-Полтавської тектонічної структури.

Ключові слова: водозабори, бучачько-канівський водоносний комплекс, трансформачія якості підземних вод, гідрогеохімічний моніторинг, прогнозні ресурси.

С. М. Левонюк, В. В. Самойлов, И. В. Удалов, В. А. Петик. ЭКОЛОГО-ГИДРОГЕОЛОГИЧЕСКИЕ ФАКТОРЫ ДЕСТАБИЛИЗАЦИИ КАЧЕСТВЕННОГО СОСТАВА ПИТЬЕВЫХ ПОДЗЕМНЫХ ВОД ЦЕНТРАЛЬНОЙ ЧАСТИ ДДАБ. Работа посвящается актуальной экологической теме - исследованию дестабилизации качества питьевых подземньх вод в условиях современного интенсивного техногенеза геологической среды. Авторами обоснованы 2 составляющие данной проблемы: определение эколого-гидрогеологических факторов влияния на качественный состав вод и обоснование экологически безопасного использования этих вод.

На базе рачионального комплексирования геологических, эколого-гидрогеологических и неотектонических условий территории работ выявлены факторы влияния на качественный состав подземных вод на бучакско-каневских водозаборах. Благодаря этому - предложены приоритетные показатели качества этих вод для гидрогеохимического мониторинга в условиях инфильтрации загрязняющих веществ с поверхности и их подтока снизу в зонах влияния тектонических структур. Установленная связь факторов влияния с качественным составом позволила разработать эколого-гидрогеологический подход к экологически безопасному использованию вод ияелевого комплекса в пределах Восточной Украиньл. Весь комплекс выполненных исследований апробирован на сети водозаборов Полтавской городской агломерации. Установлены уровни загрязнения подземных вод и обоснован оптимальный общий водоотбор на водозаборах города. Выявлена и количественно оценена прямая позитивная связь изменения содержания характерных элементов-индикаторов влияния на экологогидрогеологическое состояние подземных вод от величины водоотбора в зоне непосредственного влияния тектонических нарушений Восточно-Полтавской тектонической структуры.

Ключевые слова: водозаборы, бучакско-каневский водоносный комплекс, трансформачия качества подземных вод, гидрогеохимический мониторинг, прогнозные ресурсы.

Introduction. As it is known, the problem of supplying the population with high-quality drinking groundwater is urgent for Ukraine. It is particularly acute within Eastern Ukraine, as there is a significant man-made pressure on the geological environment (GE) and, in particular, the drinking groundwater.
Buchak-kaniv aquifer (BKA) is one of the main sources of drinking groundwater in the studied area. The water from this aquifer has historically been characterized by high quality and a stable chemical composition. But recently the composition of these waters has undergone significant transformational changes. There are the local elevated values of ele-

(C) Levoniuk S. M., Samoilov V. V., Udalov I. V., Petik V. O.

https://doi.org/10.26565/2410-7360-2019-51-15 
ments of both technogenic (surface) and natural (neotectonic) characters [5].

The current measures to control these changes, based on existing methodological recommendations $[3,7$, etc.], are: - significantly expensive and resource-intensive; - requiring considerable time to collect, analyze data and develop appropriate recommendations. It is unacceptable in today's economic and environmental context.

Therefore, one of the key tasks of ecologists and hydrogeologists is to develop two components of a methodological approach for solving this problem. First, establishment of the ecologicalhydrogeological factors of influence on the qualitative composition of groundwater. Due to improved recommended measures to changes in groundwater quality at the strategically important existing water intakes in the region will be controlled. In comparison with the existing measures, it is necessary to increase their efficiency by reducing costs and time for researches and analysis of the results. This will allow us to increase the speed of management decision- making to stabilize the composition of these waters.

Secondly, a justification of the ecologically safe use of BKA groundwater within the region of work. It is necessary to create a reserve of the high quality waters of target aquifer within the studied area. This problem has not been solved at all, but in the conditions of constant deterioration of these waters' quality it is very relevant.

Literature review. Many scientists have addressed the issues related to a study of the factors of groundwater quality deterioration and, on its basis, a development of measures to control changes in water composition and stabilization of water quality. It was papers both for the existing facilities (an improvement of ecological and geological researches of GE and, in particular, hydrogeochemical monitoring of groundwater), and for perspective ones (justification of areas determination for ecologically safe use of groundwater, creation of new water intake networks, etc.).

The main domestic and foreign studies, which are of great scientific interest to the authors, are given below.

One of the founders of modern methodology of ecological and geological researches of GE of Ukraine is Yakovlev Y. O. In the papers [1, 12], the scientist recommended, among other things, to include the GE zone of initial preservation as the boundaries of research territories. The hydrogeological substantiation of these boundaries was proposed on the basis of two levels of influence on GE hydrogeofiltration and the hydrogeochemical (hydrogeomigration) levels. Also a study of the pollution levels (including groundwater) on the basis of chemical elements background values has been further developed.

In the papers of Udalov I. V., Reshetov I. K., Amdzadi A. and others $[10,14]$ the use of the comprehensive approach in the ecological-geological studies of geological environment on the example of Eastern Donbas were described. It was recommended when assessing the level of GE components contamination (including groundwater) instead of the imperfect and outdated current norms, standards, etc. to use the indicators of geological background of area, which must be determined from the relevant values within the sites, which are distant from the centers of pollution and with minimal technogenic influence. The 4-degree levels of GE contamination have also been developed, from the satisfactory level to the threatening level.

Kononenko A. V., Lurie A. I. and Udalov I. V. in the article [17] developed the criteria to estimate the contamination levels of drinking groundwater for cretaceous water intakes of Eastern Ukraine with systematic hydrogeochemical monitoring at the local level. The basis is the priority indicators of water chemical composition, for which we observe an excess of maximum permissible concentrations (MPC) according to the current norms within the region of work. The authors have determined the following levels of contamination: within acceptable limits up to 1 MPC, relatively polluted - within 1-2 MPC, contaminated - 2-3 MPC, heavily contaminated more than 3 MPC.

In the papers of Yakovlev V. V. and Kononenko A. V. $[4,11]$, a scheme of rational placement of new cretaceous water intakes in the undeveloped areas of sandy river terraces along the Siversky Donets river and its tributaries with a possibility of further transportation of drinking high-quality water to the consumers was proposed within some territories of Eastern Ukraine. According to the articles, the active water exchange within the sandy river terraces causes a formation of large reserves of groundwater of high drinking quality. To justify this hypothesis, the prospective groundwater resources within the selected sites were calculated.

Modern papers of foreign scientists on an issue of quality control of drinking groundwater differ in breadth of coverage.

The articles by Molinari A., Guadagnini L., Marcaccio M. [18], Preziosi E., Parrone D., Del Bon A. [20], Dalla Libera N., Fabbri P., Mason L. [16] and others were aimed at developing a methodological approach to determine the most accurate geological background values of elements-indicators of groundwater qualitative composition. It is generally believed that a determination of the geological base content of components is one of the key factors in modeling the changes in the hydrochemical charac- 
teristics of groundwater and identifying the causes of these changes. Thus, foreign scientists, when determining the real state of qualitative composition of waters, consider it more appropriate to compare the current content of component with the local geological background instead of the different norms, standards, etc.

The researchers, such as Weiwu Yan, Jialong Li, Xiaohui Bai [22], Abtahi M., Golchinpour N., Yaghmaeian K. [13] and some others developed a methodological approach to the assessment of water quality for standardization of these processes and to increase the efficiency when making management decisions to stabilize the composition of these waters. This was achieved by selecting only the locally important water quality indicators and establishing the relevant weighting factors for each of them.

The problem of operation modes optimization at the water intakes against the background of groundwater quality deterioration in them is urgent for scientists from different territories of the world. A special attention is given to this problem in the large and environmentally unstable agglomerations: Y. Chen, D. Han, J. Szabo, J. Hall in the USA cities [15, 21], S. Nurani Zulkifli, H. Abdul Rahim, W.-J. Lau in Kuala-Lumpur (Malaysia) [19], Y. Weiwu, L. Jialong, B. Xiaohui in Shanghai (China) [22] and others.

At present, the main disadvantage of foreign studies in this area is a lack of the comprehensive approach to solving the problem of assessing the drinking groundwater quality at the operational water intakes and developing the appropriate prompt measures to identify its quality deterioration.

Identification of previous unsolved parts of the general problem. The ecological and hydrogeological conditions that have led to the gradual deterioration of drinking groundwater quality are now present in the central part of DDAB. But the problem of stabilization of its chemical composition is still unresolved. The existing measures are not effective enough against the background of the current economic and environmental realities. According to the authors, it is necessary to solve this problem based on 2 components:

- identification of the destabilization factors of groundwater quality in the existing water intakes;

- development of the ecologicalhydrogeological approach to ecologically safe use of drinking groundwater according to the identified factors.

Within the studied area, one of the strategic groundwater reserves is BKA. Therefore, the authors solved the above-mentioned problem by testing the performed researches on the waters of this aquifer.
The purpose of the paper is 2 components of a study of the BKA groundwater quality deterioration: - identification of the ecological and hydrogeological factors of influence on the water qualitative composition; - ensuring environmentally safe use of groundwater.

Tasks of the research: 1) to identify factors of influence on the qualitative composition of groundwater at the existing networks of Buchak-Kaniv water intakes of the investigated area and, on the basis of this, to propose the measures for hydrogeochemical monitoring of this water;

2) to justify a methodological approach for ensuring environmentally safe use of groundwater for the long term;

3) to carry out an approbation of the performed researches on the example of network of water intakes of Poltava city agglomeration.

Research novelty of the obtained results: the factors of influence on the qualitative composition of groundwater at the Buchak-Kaniv water intakes were revealed for the first time on the basis of the analysis of geological, ecological-hydrogeological and neotectonic conditions of region;

- on the basis of these factors - the priority indicators of BKA water quality for its systematic hydrogeochemical monitoring under the infiltration of pollutants from the surface and their inflow from below in the zones of influence of tectonic structures have been proposed;

- for the first time a direct positive correlation between a change of the content of characteristic indicator elements of influence on the ecologicalhydrogeological state of groundwater (mineralization, $\mathrm{Cl}^{-}, \mathrm{F}^{-}, \mathrm{Fe}_{\text {total }}, \mathrm{Br}^{-}, \mathrm{B}^{3+}, \mathrm{J}^{-}$) and the value of total water withdrawal in the zone of direct influence of tectonic faults of East-Poltava tectonic structure has been found;

- an approach for the ecologically safe use of target aquifer waters within the Buchak-Kaniv water intakes of Eastern Ukraine, based on the established correlation between the factors of influence and the qualitative composition of waters, has been developed.

Practical significance. Due to an approbation of the proposed water quality control system at Poltava water intakes network, which is strategically important within the region of research, an optimization of the total water withdrawal at the water intakes has been justified (the recommended limit is 50-60 thousand $\mathrm{m}^{3} /$ day).

The perspective areas for location of new water intakes within a $40 \mathrm{~km}$ radius around Poltava city have been identified (a total area $-750 \mathrm{~km}^{2}$ ). The estimated resources of drinking groundwater (54.5 thousand $\mathrm{m}^{3} /$ day) have been calculated. As these resources are in use, it is possible to gradually re- 
place the current water supply of urban agglomeration with high-quality groundwater.

Materials and methods of research. The authors' research is based on an analysis of the results of over 700 groundwater chemical analyses of the target aquifer within the region of work. Chemical researches have been carried out during the period of active man-made pressure on the GE of studied territory (1960-2015).

Geological and ecological information has been also used - data about the technogenic pressure on the groundwater of territory (a water withdrawal at the high power water intakes, the level regime of exploited aquifers, a presence of the existing and potential sources of depletion and pollution of groundwater and a character of their location, etc.). The available current data of neotectonic conditions of studied area have been also used. The basis has been tectonic structure along the reflection horizon $\mathrm{IVb}(\mathrm{T})$ [2], the tectonic faults can affect the hydrogeological conditions of zone of active water exchange within it.

The following methods of obtaining, processing and interpretation of necessary ecologicalhydrogeological data have been used in the work: field, chemical-analytical, comparative and graphical methods. In addition, a number of the common research methods have been used for the information processing - an analysis, a synthesis, a systematization, a classification, a modelling. Mathematical and statistical methods have been also used in the processing of received large data set. The interpolation and analogy methods have been used to simulate changes in the groundwater hydrochemical features using MapInfo Professional 10.0.

Results and discussion. The authors have found that the dominant factors in the formation of groundwater composition of buchak-kaniv aquifer at the present time are natural phenomena, which have been activated by deep hydrogeomigration processes and the anthropogenic component. This is indicated by the transformation of water quality during the period of active man-made pressure on GE of region (1960-2015) towards an increase in the content of characteristic components $\left(\mathrm{Cl}^{-}, \mathrm{F}^{-}, \mathrm{Fe}_{\text {total }}, \mathrm{Br}^{-}, \mathrm{B}^{3+}\right.$, $\left.\mathrm{J}^{-}\right)$. But also, the increased values of surface pollutants are occasionally found in waters $\left(\mathrm{NO}_{2}{ }^{-}, \mathrm{NH}_{4}{ }^{+}\right.$ and some others).

According to these influencing factors the quality of groundwater composition, it was necessary to develop the appropriate measures to control changes in the quality of these waters. In doing so, they should: - include these characteristics and reasons for changes in the water composition; - be effective, operative and economically advisable when making the appropriate management decisions.
The recommendations are given for both existing water intakes networks and new ones. To improve the system of hydrogeochemical monitoring was the most advisable for the existing ones. For new ones - a justification of determination of perspective areas for the location of new water intakes networks to solve the problem of shortage of drinking groundwater of acceptable quality within the works territory.

In the paper, the authors have tested the performed research on the example of water intakes network of Poltava city agglomeration that is strategically important within this region. A large number of the evenly located water intakes and the good ecological and hydrogeological study of area indicate a possibility of organizing these works without additional economic cost.

Recommendations for the existing water intakes networks. The authors have identified 2 levels of the required monitoring work - general and special.

1) General level. The works are carried out within the area of influence of investigated water intakes network on GE. The boundaries of influence can be determined in 3 options, depending on the available actual data.

First, the hydrogeofiltration level of water intakes impact on GE. In view of the fact that the ecological changes occur with a stable disturbance of the dynamic equilibrium of GE, ecologically significant boundaries of changes in hydrogeofiltration conditions can be attributed to the area of depression funnels with a lowering of the water level that exceeds the natural average long-term fluctuations of groundwater level [1]. That is, the boundaries of local depression funnel that appeared because of the operation of investigated water intakes may be these limits.

Secondly, the hydrogeochemical level of influence on GE. In this case, the boundaries may be the limits of groundwater zone with changed (compared with geological base values) composition.

In the third case, in the absence of other data, it is possible to use the territory of the third zone of sanitary protection that would be calculated for the investigated water intake. The boundaries of this zone are determined according to the hydrodynamic calculations [9]. The initial conditions are if the microbial (unstable) and/or the chemical (stable) pollutants fall into the aquifer outside this zone, they will not reach the water intake or reach the estimated time (at least 25 years).

The recommendations developed by the authors for hydrogeochemical monitoring are based on the following:

- priority groundwater quality indicators with the established elevated values in the waters of tar- 
get aquifer have been identified. This significantly reduces time and cost of work in comparison with the full range of hydrogeochemical studies;

- criteria for assessing groundwater pollution levels for these indicators have been proposed. This allows increasing the efficiency when making management decisions to stabilize groundwater quality.

It is known that one of the main characteristics of technogenic geochemical anomaly is its intensity, determined by the degree of chemical elements accumulation in comparison with the geological base content (GBC). Therefore, the proposed criteria for assessing groundwater pollution levels are based on the use of average elements GBC that has been defined by the authors for the waters of the territory.
GBC has been determined from the relevant values within the territories that are far from the sources of pollution and with minimal technogenic influence. In the case of absence of these data, MPC of an element has been used according to the current standards [3].

3 levels of water pollution have been identified (Table 1). The unpolluted water: the content of researched component - if the data of average geological base content are available - up to $1 \mathrm{GBC}$ inclusive, if this data are missing - up to $1 \mathrm{MPC}$ inclusive. The relatively polluted water: from 1 to $1.5-2$ GBC or from 1 to 3 MPC respectively. The contaminated water: 1.5-2 GBC and more or $3 \mathrm{MPC}$ and more respectively.

The proposed levels of groundwater pollution during general monitoring work

\begin{tabular}{|c|c|c|c|c|}
\hline \multirow[b]{3}{*}{$\begin{array}{c}\text { Name of the indicator, } \\
\text { units }\end{array}$} & \multicolumn{4}{|c|}{ Groundwater pollution levels } \\
\hline & \multicolumn{2}{|c|}{ unpolluted water } & \multirow{2}{*}{$\begin{array}{l}\text { relatively polluted } \\
\text { water } \\
\text { (a time of making } \\
\text { management deci- } \\
\text { sions) }\end{array}$} & \multirow[b]{2}{*}{$\begin{array}{l}\text { The contami- } \\
\text { nated water }\end{array}$} \\
\hline & $\begin{array}{l}\text { Within the aver- } \\
\text { age GBC }\end{array}$ & $\begin{array}{c}\text { Within the cur- } \\
\text { rent standards } \\
\text { [3] }\end{array}$ & & \\
\hline \multicolumn{5}{|c|}{ physical and chemical indicators } \\
\hline Mineralization, $\mathrm{mg} / \mathrm{dm}^{3}$ & $\leq 1150$ & $\leq 1000$ & $1150-2300$ & $\geq 2300$ \\
\hline $\mathrm{pH}$ & $\leq 7,6$ & $6,5-8,5$ & $7,6-11,4$ & $\geq 11,4$ \\
\hline $\mathrm{Cl}^{-}, \mathrm{mg} / \mathrm{dm}^{3}$ & $\leq 275$ & $\leq 250$ & $275-550$ & $\geq 550$ \\
\hline $\mathrm{Fe}_{\text {total }}, \mathrm{mg} / \mathrm{dm}^{3}$ & $\leq 0,25$ & $\leq 0,2$ & $0,25-0,5$ & $\geq 0,5$ \\
\hline \multicolumn{5}{|c|}{ sanitary and toxicological indicators } \\
\hline $\mathrm{Na}^{+}+\mathrm{K}^{+}, \mathrm{mg} / \mathrm{dm}^{3}$ & $\leq 300$ & $\leq 200$ & $300-600$ & $\geq 600$ \\
\hline $\mathrm{F}^{-}, \mathrm{mg} / \mathrm{dm}^{3}$ & $\leq 2,0$ & $\leq 1,5$ & $2,0-4,0$ & $\geq 4,0$ \\
\hline $\mathrm{NH}_{4}^{+}, \mathrm{mg} / \mathrm{dm}^{3}$ & $\leq 0,3$ & $\leq 0,5$ & $0,3-0,6$ & $\geq 0,6$ \\
\hline $\mathrm{NO}_{2}^{-}, \mathrm{mg} / \mathrm{dm}^{3}$ & $\leq 0,1$ & $\leq 0,1$ & $0,1-0,2$ & $\geq 0,2$ \\
\hline $\mathrm{Si}, \mathrm{mg} / \mathrm{dm}^{3}$ & no data available & $\leq 10$ & $10-30$ & $\geq 30$ \\
\hline \multicolumn{5}{|c|}{ physical and chemical+Sanitary and toxicological indicators } \\
\hline $\begin{array}{c}\mathrm{Br}^{-}+\mathrm{B}^{3+}+\mathrm{J}^{-} \text {(total) } \\
\mathrm{mg} / \mathrm{dm}^{3}\end{array}$ & $\leq 0,5$ & $\leq 0,55$ & $0,5-1,0$ & $\geq 1,0$ \\
\hline
\end{tabular}

It is also necessary to carry out the hydrogeological observations (control of water withdrawal and level regime) within the whole established territory of influence of the studied water intakes network on GE. The most relevant is information about the edge areas. It allows us to quickly monitor changes in the boundaries of this zone.

General monitoring level in the water intakes network of Poltava city. The territory of distribution of BKA modern local depression funnel, which appeared due to the operation of investigated water intakes, has been proposed as the boundaries of works territory (Figure 1). The boundaries of territory against the background of active technogenesis of area are constantly changing, so the role of hydrogeological data of edge water intakes is increasing.
It is also important to control the depth of depression funnel within the city.

An analysis of the groundwater chemical composition of target aquifer within the researched territory has showed that the waters composition at the water intakes of Poltava city is diverse enough according to the local ecological and hydrogeological conditions (Table 2). Unpolluted, relatively polluted water and even contaminated water is observed (in terms of $\mathrm{Fe}_{\text {total }}, \mathrm{F}^{-}, \mathrm{Br}^{-}+\mathrm{B}^{3+}+\mathrm{J}^{-}$and periodic increase of $\mathrm{NH}_{4}{ }^{+}$and $\mathrm{NO}_{2}{ }^{-}$content).

2) Special level. The monitoring studies should be conducted within the areas with the greatest transformational changes in the groundwater quality. As a result of active influence of neotectonic processes, the processes of deep mineralized groundwater discharge into the drinking waters of a zone of 


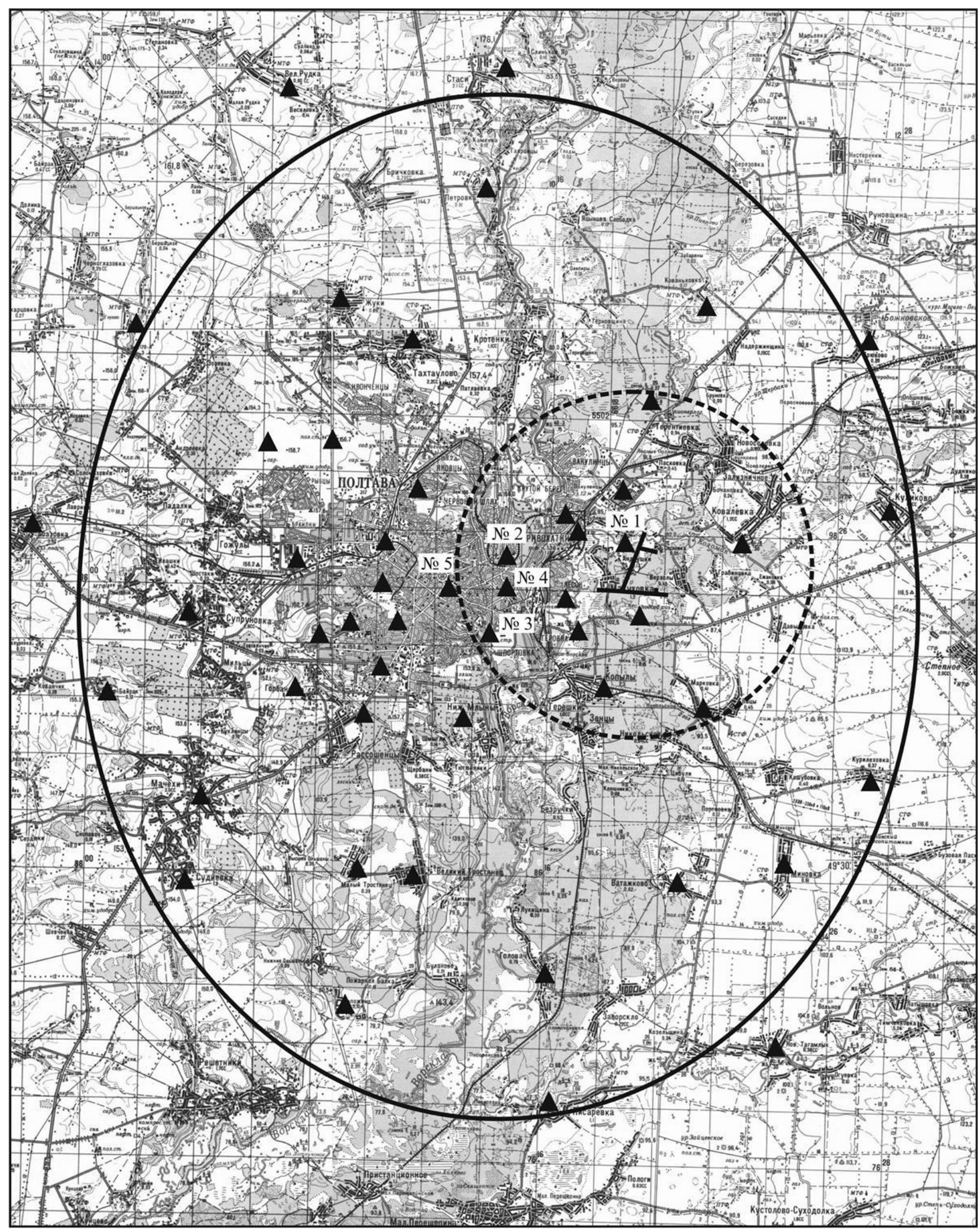

Legend:

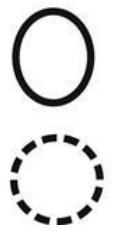

The territory of proposed general level ecological-hydrogeological monitoring studies
$\perp$
The tectonic faults within
the East Poltava tectonic
the East Poltava tectonic structure
- The buchak-kaniv water intakes

The territory of proposed special level

ecological-hydrogeological monitoring studies

Fig. 1. The map-scheme of territories of proposed general and special levels of ecological-hydrogeological (first of all, hydrogeochemical) monitoring studies for the water intakes of Poltava city 
The levels of groundwater pollution at the water intakes of Poltava city

\begin{tabular}{|c|c|c|}
\hline \multirow{2}{*}{$\begin{array}{l}\text { Name of the indicator, } \\
\text { units }\end{array}$} & \multicolumn{2}{|c|}{$\begin{array}{c}\text { Groundwater state in Poltava water intakes, } \\
\text { pollution level (indicator content) }\end{array}$} \\
\hline & $\begin{array}{c}\text { water intakes in the eastern part of } \\
\text { territory }\end{array}$ & other water intakes \\
\hline \multicolumn{3}{|c|}{ physical and chemical indicators } \\
\hline Mineralization, $\mathrm{mg} / \mathrm{dm}^{3}$ & $\begin{array}{l}\text { Relatively polluted } \\
\quad(1352-1400)\end{array}$ & $\begin{array}{l}\text { Unpolluted } \\
(700-1100)\end{array}$ \\
\hline $\mathrm{pH}$ & $\begin{array}{l}\text { Relatively polluted } \\
\qquad(8,3-9,2)\end{array}$ & $\begin{array}{c}\text { Relatively polluted+ } \\
\text { Unpolluted } \\
(6,3-8,9) \\
\end{array}$ \\
\hline $\mathrm{Cl}^{-}, \mathrm{mg} / \mathrm{dm}^{3}$ & $\begin{array}{l}\text { Relatively polluted } \\
\text { (about 550) }\end{array}$ & $\begin{array}{c}\text { Relatively polluted+ } \\
\text { Unpolluted } \\
(199-348)\end{array}$ \\
\hline $\mathrm{Fe}_{\text {total }}, \mathrm{mg} / \mathrm{dm}^{3}$ & $\begin{array}{l}\text { Contaminated } \\
\text { (about } 1,2)\end{array}$ & $\begin{array}{c}\text { Contaminated+ } \\
\text { Relatively polluted+ } \\
\text { Unpolluted } \\
(0,1-2,2) \\
\end{array}$ \\
\hline \multicolumn{3}{|c|}{ sanitary and toxicological indicators } \\
\hline $\mathrm{Na}^{+}+\mathrm{K}^{+}, \mathrm{mg} / \mathrm{dm}^{3}$ & Relatively polluted (368-449) & Relatively polluted (295-371) \\
\hline $\mathrm{F}^{-}, \mathrm{mg} / \mathrm{dm}^{3}$ & Contaminated (about 7,0) & $\begin{array}{c}\text { Contaminated }+ \\
\text { Relatively polluted }(2,4-4,2)\end{array}$ \\
\hline $\mathrm{NH}_{4}{ }^{+}, \mathrm{mg} / \mathrm{dm}^{3}$ & \multicolumn{2}{|c|}{ Contaminated+Relatively polluted+Unpolluted $(0,0-0,8)$} \\
\hline $\mathrm{NO}_{2}^{-}, \mathrm{mg} / \mathrm{dm}^{3}$ & \multicolumn{2}{|c|}{ Contaminated+Relatively polluted+Unpolluted $(0,0-1,0)$} \\
\hline $\mathrm{Si}, \mathrm{mg} / \mathrm{dm}^{3}$ & \multicolumn{2}{|c|}{ Relatively polluted $(12,8-15,4)$} \\
\hline \multicolumn{3}{|c|}{ The physical and chemical+Sanitary and toxicological indicators } \\
\hline $\begin{array}{c}\mathrm{Br}^{-}+\mathrm{B}^{3+}+\mathrm{J}^{-}(\text {total }) \\
\mathrm{mg} / \mathrm{dm}^{3}\end{array}$ & Contaminated (about 1,25 ) & $\begin{array}{c}\text { Contaminated }+ \\
\text { Relatively polluted }(0,55-1,2)\end{array}$ \\
\hline
\end{tabular}

active water exchange are characteristic within the researched region. Numerous faults within the tectonic structures serve as migration zones. As established by the authors [5], gradual change in the chemical composition of waters to the chloridesodium type and the increase in salt content occur under the influence of neotectonic factor. The groundwater concentration of some macro- and micro-components is also increasing to non-GBC.

The boundaries of a special level of monitoring studies are the territories where the maximum influence of described above natural processes on the quality of groundwater is possible. The authors found that these are the areas of intersection of in- fluence zones of powerful water intakes and the territories within a $5 \mathrm{~km}$ radius around the hydrodynamically active tectonic faults.

Studying hydrogeochemical component in the operational modes of powerful water intakes in the region, the authors determined critical values of specific elements-indicators that revealed the abovementioned transformation processes. The stages of groundwater quality change were also defined. They formed the basis for the proposed hydrogeochemical monitoring system (Table 3 ).

Also, at the special research level, the hydrogeological part of monitoring (the observation of water withdrawal and level regime) is important for con-

Table 3

Determined stages of groundwater quality change in the areas of special monitoring researches

\begin{tabular}{|c|c|c|c|}
\hline \multirow{2}{*}{ Name of the indicator, units } & \multicolumn{3}{|c|}{ Stages of groundwater quality change } \\
\cline { 2 - 4 } & $\begin{array}{c}\text { I stage }- \text { mini- } \\
\text { mum }\end{array}$ & $\begin{array}{c}\text { II stage }- \text { indicator } \\
\text { (a time of making man- } \\
\text { agement decisions) }\end{array}$ & III stage - critical \\
\hline Mineralization, mg/dm & $\leq 1400$ & $1400-1600$ & $\geq 1600$ \\
\hline $\mathrm{Cl}^{-}, \mathrm{mg} / \mathrm{dm}^{3} / \%$ equivalent & $\leq 350 / 30$ & $350-450 / 30-35$ & $\geq 450 / 35$ \\
\hline $\mathrm{F}^{-}, \mathrm{mg} / \mathrm{dm}^{3}$ & $\leq 3,5$ & $3,5-4,0$ & $\geq 4,0$ \\
\hline $\mathrm{Br}^{-}+\mathrm{B}^{3+}+\mathrm{J}^{-}(\mathrm{total}), \mathrm{mg} / \mathrm{dm}^{3}$ & $\leq 1,0$ & $1,0-1,5$ & $\geq 1,5$ \\
\hline $\mathrm{Fe}_{\text {total }}, \mathrm{mg} / \mathrm{dm}^{3}$ & $\leq 0,5$ & $0,5-1,0$ & $\geq 1,0$ \\
\hline
\end{tabular}


trolling possible influence of technogenic component on the activation of changes in water composition. The result of these works is to obtain regularities that optimize the operational modes of studied water intakes.

The special level of monitoring in the water intakes network of Poltava city. The area of research is a $5 \mathrm{~km}$ radius around the tectonic faults within the East Poltava tectonic structure (Figure 1).

The developed recommendations were tested on the example of water intakes No. 1-5. The integrated studies of hydrogeological and hydrogeochemical components of monitoring were conducted (Figure 2). The results of chemical analyses at the Buchak-Kaniv water intakes and general data of water withdrawal by 2 major operational aquifers of region, which have a close hydraulic connection here (buchak-kaniv and cenomanian-lower cretaceous aquifers), were taken into account.

According to the results of a correlation analysis, data on the water intake No. 1 shows a direct positive correlation between a change of the content of characteristic indicator elements and the value of total water withdrawal in the area of direct influence of tectonic faults (a distance less than $0.5 \mathrm{~km}$ ). The Pearson correlation coefficients $r=0.70-0.90$ were calculated. At the same time, for the other water intakes (a distance is about 3.2-5 km) $\mathrm{r}=0.43-0.68$.

As a result, regularities that allowed substantiating optimization of total water withdrawal within the water intake network of Poltava city were obtained. For the content of the studied components within the whole zone of special monitoring not to exceed the established critical values (Table 3 ), it is necessary to extract $\mathrm{r}$ up to 100 thousand $\mathrm{m}^{3} /$ day water. And for the gradual restoration of disturbed constant ecological balance in the solution-rock system and a return of the hydrogeochemical parameters to the geological base content, it is necessary not to increase the modern pressure on the groundwater. That is, the total water withdrawal should be up to $50-60$ thousand $\mathrm{m}^{3} /$ day.

Recommendations for new water intakes networks. Determination of perspective areas for the location of new water intakes of different capacity, with a possibility of further transportation of high quality drinking water to the consumers to solve the problem of drinking groundwater shortage of acceptable quality within the territory was justified.

A methodological approach to the allocation of sites is based on a complex system of ranking the territory by the degree of risk of groundwater contamination [6], developed by the authors.

The promising areas are considered according to 3 parameters.

1) The indicator of groundwater protection from technogenic pollution, which comes during the process of downward vertical filtration and migration from the earth's surface. It was calculated as the sum of 5 indexes that are multiplied by rating (weighting) coefficients:

- index of lithology of the upper (near-surface)

part of cross-section (the weighting factor 1.5);

- index of own geological protection of the first inter-layer aquifer (the weighting factor 5);

- sediments permeability index of the first interlayer aquifer (the weighting factor 1.5);

- permeability index of a separate layer (the weighting factor 10);

- rate index of vertical flow through the separate layer (the weighting factor 10).

2) The indicator of groundwater protection from the possible transformation of composition as a result of the active influence of neotectonic processes. It depends on 2 indexes: the distance to the nearest established tectonic faults; the total amplitudes of neogene-quaternary movements of the Earth's crust as a parameter that maximally influences on the activity of hydrogeomigration processes within these faults.

3) A thickness of the reservoir rocks of target aquifer. This indicator is correlated with the value of water enrichment of aquifer. An use this index makes it possible to design forward-looking water intakes with varied capacity.

In terms of a result of GIS calculations, the perspective areas for location of new water intakes within a $40 \mathrm{~km}$ radius around Poltava city were identified (Figure 3). The territories are divided into 2 categories:

- perspective for the location of new low and medium power water intakes (an area of about 470 $\mathrm{km}^{2}$ ). Concentrated in the southern, western and northwestern parts of region. They are characterized by high and conditional groundwater protection from the possible surface contamination. Also these areas are favorable in view of the neotectonic conditions - a distance to the territories with established tectonic faults and with significant amplitudes of neogene-quaternary movements of the Earth's crust (150 $\mathrm{m}$ and more) is more than $5 \mathrm{~km}$;

- perspective for the location of new high power water intakes (about $280 \mathrm{~km}^{2}$ ). Located to the south and northwest of city. In addition to the ecological-hydrogeological advantages of previous areas, there are the reservoir sands of Buchak-kaniv aquifer with the highest thickness - more than $30 \mathrm{~m}$. That is, the potential volume of exploitation resources of aquifer within these territories is the maximum.

According to the method of areal differentiation of underground flow module in terms of the papers $[4,11]$, the authors calculated the projected resources of BKA drinking groundwater within the 

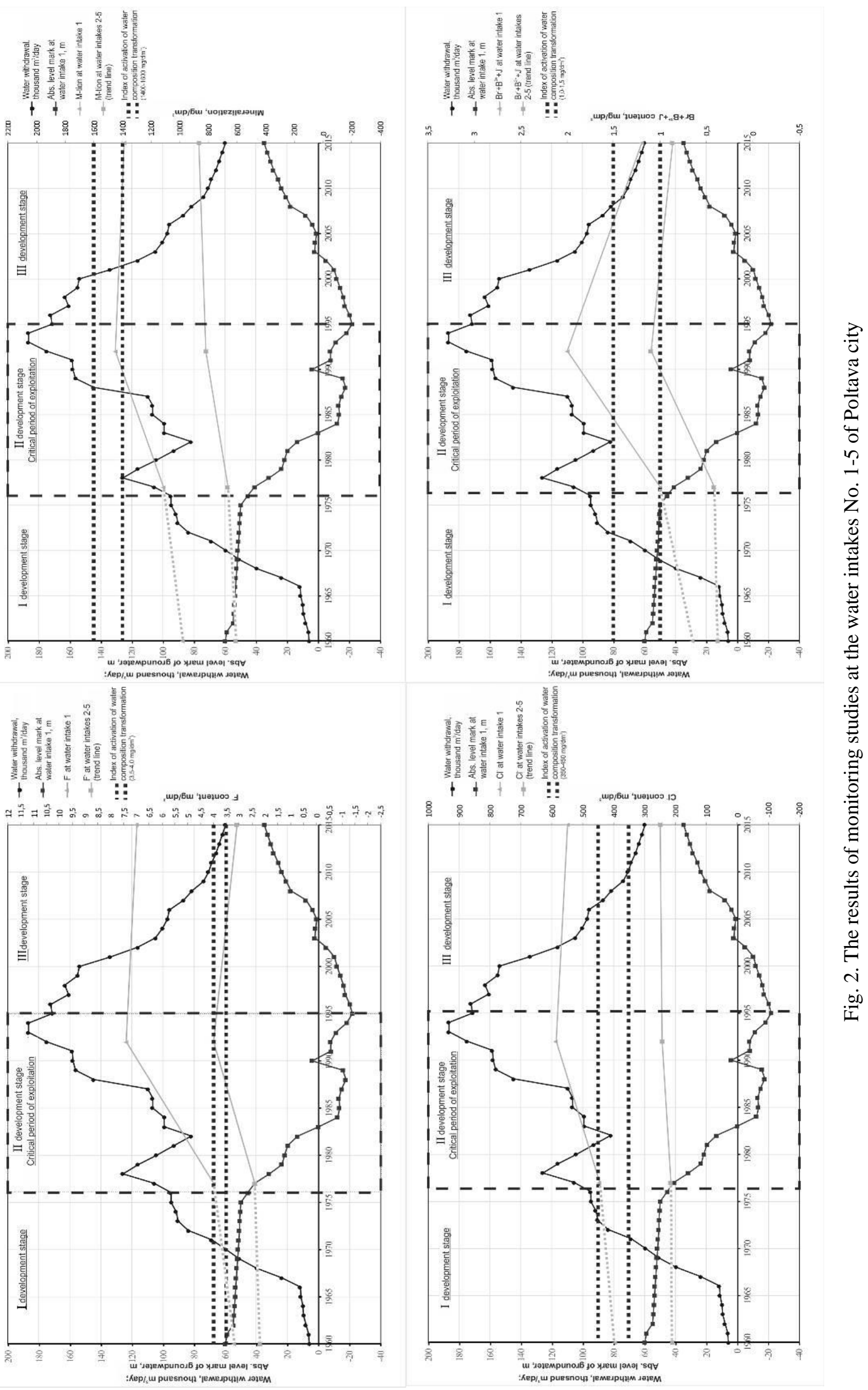


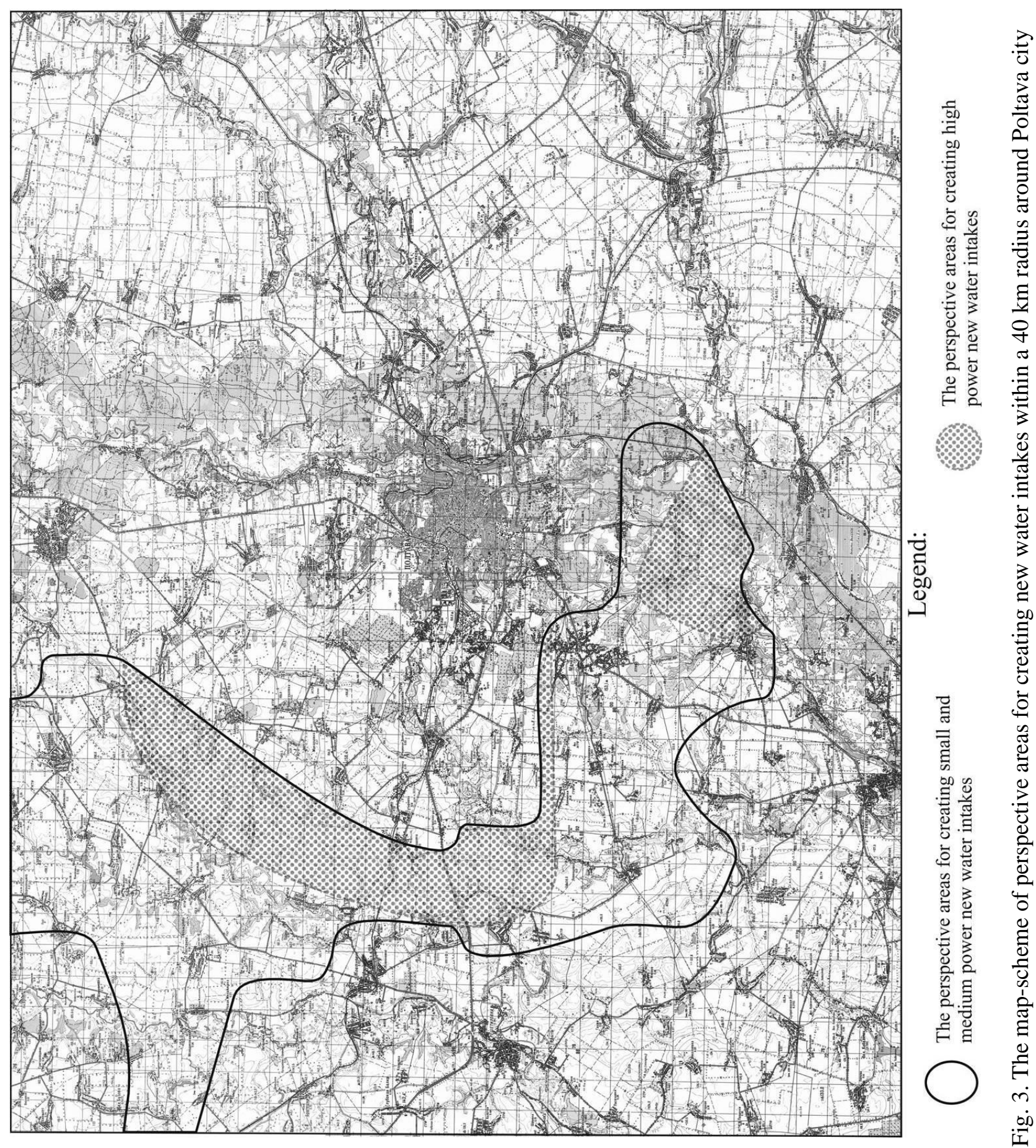

perspective sites by the formulas:

1) $\mathrm{M}_{\mathrm{uf}}=\mathrm{M}_{\mathrm{o}} \mathrm{F}_{\mathrm{o}} /\left[\mathrm{F}_{\mathrm{s}}+\left(\mathrm{F}_{\mathrm{o}}-\mathrm{F}_{\mathrm{s}}\right)\left(\mathrm{C}_{\mathrm{s}} / \mathrm{C}_{\mathrm{r}}\right)\right]$,

where $\mathrm{M}_{\mathrm{uf}}$ - the underground flow module for the established sites, $\mathrm{dm}^{3} / \mathrm{s} * \mathrm{~km}^{2} ; \mathrm{M}_{\mathrm{o}}$ - the average value of underground flow module for the target aquifer of region $(0,74$ - according to Rudenko, $\mathrm{F}$. A. (1971). Hydrogeology of the USSR, vol. V), $\mathrm{dm}^{3} / \mathrm{s} * \mathrm{~km}^{2} ; \mathrm{F}_{\mathrm{o}}-\mathrm{a}$ total area of the territory within a $40 \mathrm{~km}$ radius around Poltava city, $\mathrm{km}^{2} ; \mathrm{F}_{\mathrm{s}}$ - an area of the researched sites, $\mathrm{km}^{2} ; \mathrm{C}_{\mathrm{s}}-$ the indicator of mineralization of target groundwater within the studied sites, $\mathrm{mg} / \mathrm{dm}^{3} ; \mathrm{C}_{\mathrm{r}}$ - the indicator of mineralization of target groundwater within another part of the territory with a $40 \mathrm{~km}$ radius around Poltava city, $\mathrm{mg} / \mathrm{dm}^{3}$;
2) $\mathrm{Q}_{\mathrm{prs}}=\mathrm{M}_{\mathrm{uf}} * \mathrm{~F}_{\mathrm{s}}$.

The obtained perspective resources $\left(\mathrm{Q}_{\mathrm{prs}}\right)$ amounted to $630 \mathrm{dm}^{3} / \mathrm{s}$ or 54.5 thousand $\mathrm{m}^{3} /$ day, which is approximately equal to the current total water withdrawal of drinking groundwater at the water intakes of Poltava city (50-60 thousand $\mathrm{m}^{3} /$ day). That is, due to the using of these resources it is possible to gradually replace the current water supply of urban agglomeration with high-quality groundwater.

Conclusions. There are 2 science-based components of the research of groundwater quality deterioration of BKA within the central part of DDAB in the paper: - a determination of the ecological-hydrogeological factors of influence on the qualitative 
composition of these waters; - a justification of the ecologically safe groundwater use.

Based on the analysis of geological, ecologicalhydrogeological and neotectonic conditions of the region, the factors of influence on the groundwater qualitative composition at the Buchak-Kaniv water intakes, which are grouped into the factors of technogenic (surface) and natural (neotectonic) character, have been identified.

The priority indicators of BKA water quality for its systematic hydrogeochemical monitoring under the infiltration of pollutants from the surface and their inflow from below in the zones of influence of tectonic structures have been proposed. It is recommended to control their contents on the basis of 2 levels - general (a control of the whole complex of actual pollutants in the areas of water intakes influence) and special (a control of mineralization, $\mathrm{Cl}^{-}$, $\mathrm{F}^{-}, \mathrm{Fe}_{\text {total }}, \mathrm{Br}^{-}, \mathrm{B}^{3+}, \mathrm{J}^{-}$in the areas of intersection of influence zones of powerful water intakes and the territories within a $5 \mathrm{~km}$ radius around the hydrodynamically active tectonic faults).

An approach for the ecologically safe use of target aquifer waters within Eastern Ukraine, based on the established correlation between the factors of influence and the qualitative composition of waters, has been developed. The high-quality groundwater sites for further transportation of these waters to the consumers have been justified.
The whole complex of performed researches was tested on the network of water intakes of Poltava city agglomeration, which is strategically important within the region. The levels of groundwater contamination at the water intakes have been established. The unpolluted, relatively polluted water and even contaminated water were observed (in terms of $\mathrm{Fe}_{\text {total }}, \mathrm{F}^{-}, \mathrm{Br}^{-}+\mathrm{B}^{3+}+\mathrm{J}^{-}$and periodic increase of $\mathrm{NH}_{4}{ }^{+}$ and $\mathrm{NO}_{2}^{-}$content).

According to the results of correlation analysis, a direct positive correlation (the Pearson correlation coefficients $r=0.70-0.90$ ) between a change of the content of characteristic indicator elements and the value of total water withdrawal in the area of direct influence of tectonic faults of East-Poltava tectonic structure has been found. As a result, the regularities that allowed substantiating the optimization of total water withdrawal within the water intake network of Poltava city were obtained (the limit of 50-60 thousand $\mathrm{m}^{3} /$ day).

The perspective areas for location of new water intakes within a $40 \mathrm{~km}$ radius around Poltava city were identified (total area $-750 \mathrm{~km}^{2}$ ). The estimated resources of drinking groundwater (54.5 thousand $\mathrm{m}^{3} /$ day) have been calculated. Due to the using of these resources it is possible to gradually replace the current water supply of urban agglomeration with high-quality groundwater.

\section{References}

1. Временное методическое руководство по проведению комплексных эколого-геологических исследований (на территории Украины) [Техt] / под ред. Е. А. Яковлева [и др.]. - К.: ГГП «Геопрогноз», 1994. - 331 с.

2. Гузік Я. І. Узагальнення та оперативний аналіз геолого-геофізичних матеріалів в иентральній частині Дніпровсько-Донецької западини за 2007-2009 pp. [Техt] / Я. І. Гузік. - ДГП «Укргеофізика» СхідноУкраӥнська геофізична розвідувальна експедиція. - Полтава, 2009. - 85 c.

3. Державні санітарні правила і норми «Гігієнічні вимоги до води питної, призначеної для споживання людиною»: ДСанПіН 2.2.4-171-10 [Техt]. - К.: Міністерство охорони здоров'я України, 2010. - № $400 .-45$ с.

4. Кононенко А. В. Обтрунтування раціонального розміщення нових водозаборів в мергельно-крейдяному водоносному горизонті на території Східної України [Text] / A. В. Кононенко, В. В. Яковлєв // Hungarian scientific journal (electronic version of the journal), 2018. - № 23. - C. 8-14.

5. Левонюк С. М. Еколого-гідрохімічні особливості трансформації якості питних підземних вод під впливом техногенних та неотектонічних факторів (на прикладі бучачько-канівських водозаборів Східної України) [Tехt] / С. М. Левонюк, I. В. Удалов // Пошукова та екологічна геохімія, № 1 (19). - К., 2018. - С. 30-40.

6. Левонюк С. М. Комплексна геоекологічна оцінка захищеності питних підземних вод [Техт] / С. М. Левонюк, I. В. Удалов // Вісник Одеського нац. університету. Серія: «Географічні та геологічні науки». - Том 23, випуск 2 (33). - Одеса, 2018. - C. 111-133.

7. Методические рекомендации по организаџии и ведению мониторинга подземных вод (изучение режима химического состава подземных вод) [Tехt]. - М.: ВСЕГИНГЕО, 1985. - 76 с.

8. Огняник Н. С. Эколого-гидрогеологический мониторинг территорий загрязнения геологической среды легкими нефтепродуктами [Text] / Н. С. Огняник, Н. К. Парамонова, А. Л. Брикс [и др.]. - К.: LAT\&K, 2013. 254 c.

9. Рекомендации по гидрогеологическим расчетам для определения грании 2-х и 3-х поясов зон санитарной охраны подземныхх источников хозяйственно-питьевого водоснабжения [Техт] / Под ред. Е. М. Бирюковой. М.: ВНИИ «ВОДГЕО», 1983. - 102 c.

10. Удалов I. В. Еколого-геологічне картографування та моніторинг геологічного середовища: навчальний посібник [Техt] / I. В. Удалов, I. К. Решетов. - Х.: ХНУ імені В.Н. Каразіна, 2012. - 152 с.

11. Яковлев В. В. Подземные воды боровых террас как источник питьевого водоснабжения [Техт] / В. В. Яковлев // Вісник Харківського нац. університету. Сер. «Геологія - Географія - Екологія». - Х.: ХНУ імені В. Н. Каразіна, 2008. - Bun. 29. - № 824. - C. 43-48. 
12. Яковлев С. О. Еколого-геохімічна оцінка забруднення трунтів, донних відкладів, трунтових вод. Методичні рекомендації [Text] / С. О. Яковлев, І. В. Мельник, А. І. Дубицький. - К.: ДГП «Геоінформ», $1998 .-34$ с.

13. Abtahi, M. A modified drinking water quality index (DWQI) for assessing drinking source water quality in rural communities of Khuzestan Province, Iran [Text] / M. Abtahi, N. Golchinpour, K. Yaghmaeian [Eds.] // Ecological Indicators, June 2015. - Vol. 53. - P. 283-291.

14. Aziz, A. Rational integration of ecologic-geological studies [Text] / A. Aziz, I. V. Oudalov, N. Rouhollah [Eds.] // Ecology, Environment and Conservation Paper, 2015. - Vol. 21, Issue 4. - P. 1625-1631.

15. Chen, Y. Water quality monitoring in smart city: A pilot project [Text] / Y. Chen, D. Han // Automation in Construction, May 2018. - Vol. 89. - P. 307-316.

16. Dalla Libera, N. Geostatistics as a tool to improve the natural background level definition: An application in groundwater [Text] / N. Dalla Libera, P. Fabbri, L. Mason [Eds.] // Science of The Total Environment, November 2017. - Vol. 598. - P. 330-340.

17. Kononenko, A. Criteria for Assessing Groundwater Contamination Levels of Marl and Chalk Water Intakes in Eastern Ukraine [Text] / A. Kononenko, A. Lurie, I. Udalov // Eastern European Scientific Journal (Gesellschaftswissenschaften): Düsseldorf (Germany): Auris Verlag, 2018. - № 2. - P. 13-17.

18. Molinari, A. Geostatistical multimodel approach for the assessment of the spatial distribution of natural background concentrations in large-scale groundwater bodies [Text] / A. Molinari, L. Guadagnini, M. Marcaccio [Eds.] // Water Research, February 2019. - Vol. 149. - P. 522-532.

19. Nurani Zulkifli, S. Detection of contaminants in water supply: A review on state-of-the-art monitoring technologies and their applications [Text] / S. Nurani Zulkifli, H. Abdul Rahim, W.-J. Lau // Sensors and Actuators B: Chemical, February 2018. - Vol. 255, Part 3. - P. 2657-2689.

20. Preziosi, E. Natural background level assessment in groundwaters: probability plot versus pre-selection method [Text] / E. Preziosi, D. Parrone, A. Del Bon [Eds.] // Journal of Geochemical Exploration, August 2014. - Vol. 143. -P. 43-53.

21. Szabo, J. On-line Water Quality Monitoring for Drinking Water Contamination [Text] / J. Szabo, J. Hall // Comprehensive Water Quality and Purification, 2014. - Vol. 2. - P. 266-282.

22. Weiwu, Y. Comprehensive assessment and visualized monitoring of urban drinking water quality [Text] / Y. Weiwu, L. Jialong, B. Xiaohui // Chemometrics and Intelligent Laboratory Systems, July 2016. - Vol. 155. - P. 26-35.

Author's contribution: all authors made an equal contribution to this work.

UDC 504.064:556.314

\section{Serhii Levoniuk,}

Researcher, Ukrainian Scientific Research Institute for Natural Gases,

20 Himnasiyna Emb., Kharkiv, 61010, Ukraine,

e-mail: sergii.levonyuk@gmail.com, https://orcid.org/0000-0002-4073-8152;

\section{Vitaliy Samoilov,}

$\mathrm{PhD}$ (Geology), Head of the Department, Ukrainian Scientific Research Institute for Natural Gases, e-mail: samoilov_gas@ukr.net,https://orcid.org/0000-0002-0650-2808;

\section{Igor Udalov,}

Doctor of Sciences (Geology), Associate Professor, Head of the Department of Hydrogeology,

V. N. Karazin Kharkiv National University, 4 Svobody Sq., Kharkiv, 61022, Ukraine, e-mail: igorudalov8@ gmail.com, https://orcid.org/0000-0003-3844-6481;

\section{Viacheslav Petik,}

$\mathrm{PhD}$ (Technics), Senior Lecturer, Department of Hydrogeology,

V.N. Karazin Kharkiv National University,

e-mail: nemuk1310@gmail.com, https://orcid.org/0000-0002-4055-0926

\section{THE ECOLOGICAL AND HYDROGEOLOGICAL FACTORS OF QUALITATIVE COMPOSITION DESTABILIZATION OF DRINKING GROUNDWATER WITHIN THE CENTRAL PART OF DDAB}

Formulation of the problem. The paper is devoted to a topical environmental theme - a study of the destabilization of drinking groundwater quality in the conditions of modern intensive technogenesis of geological environment.

The purpose of the article is 2 components of a study of the groundwater quality deterioration of buchak-kaniv aquifer: - an identification of the ecological and hydrogeological factors of influence on the water qualitative composition; - an ensuring of the environmentally safe use of groundwater.

Materials and methods. The research is based on an analysis of the results of over 700 groundwater chemical analyses of the target aquifer within the region. The chemical researches have been carried out dur- 
ing the period of active man-made pressure on the geological environment of studied territory (1960-2015). The available current data of geological, ecological and neotectonic conditions of studied area have been also used.

The following methods of obtaining, processing and interpretation of necessary ecologicalhydrogeological data have been used in the paper: field, chemical-analytical, comparative and graphical methods. A number of the common research methods have been used for the information processing - an analysis, a synthesis, a systematization, a classification, a modeling. The mathematical and statistical methods have been also used in the processing of received large data set. The interpolation and analogy methods have been used to simulate changes in the groundwater hydrochemical features using MapInfo Professional 10.0 .

Results and scientific novelty. For the first time on the basis of analysis of geological, ecologicalhydrogeological and neotectonic conditions of region, the factors of influence on the qualitative composition of groundwater at the buchak-kaniv water intakes were revealed.

On the basis of these factors - the priority indicators of buchak-kaniv aquifer water quality for its systematic hydrogeochemical monitoring under the infiltration of pollutants from the surface and their inflow from below in the zones of influence of tectonic structures have been proposed.

For the first time a direct positive correlation between a change of the content of characteristic indicator elements of influence on the ecological-hydrogeological state of groundwater (mineralization, $\mathrm{Cl}^{-}, \mathrm{F}^{-}, \mathrm{Fe}_{\text {total }}$, $\mathrm{Br}^{-}, \mathrm{B}^{3+}, \mathrm{J}^{-}$) and the value of total water withdrawal in the zone of direct influence of tectonic faults of EastPoltava tectonic structure has been found.

An approach for the ecologically safe use of target aquifer waters within the buchak-kaniv water intakes of Eastern Ukraine, which is based on the established correlation between the factors of influence and the qualitative composition of waters, has been developed.

Practical significance. Due to an approbation of the proposed water quality control system at the Poltava water intakes network, which is strategically important within the region of research, an optimization of the total water withdrawal at the water intakes has been justified (the recommended limit is $50-60$ thousand $\mathrm{m}^{3} /$ day).

The perspective areas for location of new water intakes within a $40 \mathrm{~km}$ radius around Poltava city have been identified (a total area $-750 \mathrm{~km}^{2}$ ). The estimated resources of drinking groundwater $(54.5$ thousand $\mathrm{m}^{3} /$ day) have been calculated. Due to the using of these resources it is possible to gradually replace the current water supply of urban agglomeration with high-quality groundwater.

Keywords: water intakes, buchak-kaniv aquifer, transformation of drinking groundwater quality, hydrogeochemical monitoring, perspective resources.

\section{References}

1. Yakovlev, Ye. A. (Eds.). (1994), Vremennoe metodicheskoe rukovodstvo po provedeniyu kompleksnykh ekologogeologicheskikh issledovaniy (na territorii Ukrainy) [Temporary guidelines for the conduct of integrated environmental and geological research (in Ukraine)], Kiev: GGP «Geoprognoz», 331.

2. Guzik, Ya. I. (2009), Uzagal’nennya ta operaty`vny`j analiz geologo-geofizy`chny`x materialiv v central ’nij chasty`ni Dniprovs 'ko-Donecz'koyi zapady`ny`za 2007-2009 rr. [Generalization and operative analysis of geological and geophysical materials in the central part of Dnieper-Donetsk basin for 2007-2009], DGP «Ukrgeophysics» EastUkrainian geophysical prospecting expedition, Poltava, 85.

3. Derzhavni sanitarni pravy'la $i$ normy "Gigiyenichni vy'mogy' do vody` py`tnoyi, pry`znachenoyi dlya spozhy vannya lyudy noyu»: DSanPiN 2.2.4-171-10 [State sanitary rules and norms "Hygienic requirements for drinking water intended for human consumption": DSanPiN 2.2.4-171-10], Kyiv: Ministerstvo oxorony 'zdorov'ya Ukrayiny`, 400, 45.

4. Kononenko, A. V., Yakovlyev, V. V. (2018), Obg`runtuvannya racional'nogo rozmishhennya novy`x vodozaboriv $v$ mergel`no-krejdyanomu vodonosnomu gory`zonti na tery`oriyi Sxidnoyi Ukrayiny` [Substantiation of rational placement of new water intakes in marl-chalk aquifer in the territory of Eastern Ukraine], Hungarian scientific journal (electronic version of the journal), 23, 8-14.

5. Levonyuk, S. M., Udalov, I. V. (2018), Ekologo-gidroximichni osobly'vosti transformaciyi yakosti py'tny`x pidzemny`x vod pid vply'vom texnogenny'x ta neotektonichny'x faktoriv (na pry`kladi buchacz'ko-kanivs'ky’x vodozaboriv Sxidnoyi Ukrayiny') [Ecological-hydrochemical features of drinking groundwater quality transformation under the influence of technogenic and neotectonic factors (on the example of buchak-kaniv water intakes in Eastern Ukraine)], Search and ecological geochemistry, 1 (19), 30-40.

6. Levonyuk, S. M., Udalov, I. V. (2018), Kompleksna geoekologichna ocinka zaxy`shhenosti py`tny`x pidzemny`x vod [Comprehensive geo-environmental assessment of drinking groundwater protection], Bulletin of Odessa National University. Series: Geographical and geological sciences, 2 (33), 111-133. 
7. Metodicheskie rekomendatsii po organizatsii i vedeniyu monitoringa podzemnykh vod (izuchenie rezhima khimicheskogo sostava podzemnykh vod) [Guidelines for the organization and management of groundwater monitoring (study of the groundwater chemical composition)], Moscow: VSYeGINGYeO, 76.

8. Ognyanik, N. S., Paramonova, N. K., Briks, A. L. (Eds.). (2013), Ekologo-gidrogeologicheskiy monitoring territoriy zagryazneniya geologicheskoy sredy legkimi nefteproduktami [The ecological and hydrogeological monitoring of territories of geological environment contamination by light oil products], Kiev: LAT\&K, 254.

9. Biryukova, Ye. M. (1983), Rekomendatsii po gidrogeologicheskim raschetam dlya opredeleniya granits 2-kh i 3-kh poyasov zon sanitarnoy okhrany podzemnykh istochnikov khozyaystvenno-pitevogo vodosnabzheniya [The recommendations on hydrogeological calculations to determine the boundaries of second and third zones of sanitary protection zones of underground sources of drinking water supply], Moscow: VNII «VODGYeO», 102.

10. Udalov, I. V., Reshetov, I. K. (2012), Ekologo-geologichne kartografuvannya ta monitory`ng geologichnogo seredovy`shha: navchal`ny`j posibny`k [Ecological-geological mapping and geological environment monitoring: a textbook], Kharkiv: V. N. Karazin Kharkiv National University, 152.

11. Yakovlev, V. V. (2008), Podzemnye vody borovykh terras kak istochnik pitevogo vodosnabzheniya [Groundwater of bor terraces as a source of drinking water], Bulletin of V. N. Karazin Kharkiv National University. Series "GeologyGeography-Ecology", 29, 824, 43-48.

12. Yakovlev, Ye. O., Mel`ny`k, I. V., Duby`cz`ky`j, A. I. (1998), Ekologo-geoximichna ocinka zabrudnennya g`runtiv, donny`x vidkladiv, g`runtovy`x vod. Metody`chni rekomendaciyi [Ecological-geochemical assessment of contamination of soil, bottom sediments, groundwater. Guidelines], Kyiv: DGP «Geoinform», 34.

13. Abtahi, M., Golchinpour, N., Yaghmaeian, K. (Eds.). (2015), A modified drinking water quality index (DWQI) for assessing drinking source water quality in rural communities of Khuzestan Province, Iran. - Ecological Indicators, 53, 283-291.

14. Aziz, A., Oudalov, I. V., Rouhollah, N. (Eds.). (2015), Rational integration of ecologic-geological studies. - Ecology, Environment and Conservation Paper. 21, 4, 1625-1631.

15. Chen, Y., Han, D. (2018), Water quality monitoring in smart city: A pilot project. - Automation in Construction. 89 , 307-316.

16. Dalla Libera, N., Fabbri, P., Mason, L. (Eds.). (2017), Geostatistics as a tool to improve the natural background level definition: An application in groundwater. - Science of The Total Environment. 598, 330-340.

17. Kononenko, A., Lurie, A., Udalov, I. (2018), Criteria for Assessing Groundwater Contamination Levels of Marl and Chalk Water Intakes in Eastern Ukraine. - Eastern European Scientific Journal (Gesellschaftswissenschaften): Düsseldorf (Germany): Auris Verlag, 2, 13-17.

18. Molinari, A., Guadagnini, L., Marcaccio, M. (Eds.). (2019), Geostatistical multimodel approach for the assessment of the spatial distribution of natural background concentrations in large-scale groundwater bodies. Water Research. 149, 522-532.

19. Nurani Zulkifli, S., Abdul Rahim, H., Lau, W.-J. (2018), Detection of contaminants in water supply: A review on state-of-the-art monitoring technologies and their applications. - Sensors and Actuators B: Chemical. 255, Part 3, 2657-2689.

20. Preziosi, E., Parrone, D., Del Bon, A. (Eds.). (2014), Natural background level assessment in groundwaters: probability plot versus pre-selection method. - Journal of Geochemical Exploration. 143, 43-53.

21. Szabo, J., Hall, J. (2014), On-line Water Quality Monitoring for Drinking Water Contamination. - Comprehensive Water Quality and Purification. 2, 266-282.

22. Weiwu, Y., Jialong, L., Xiaohui, B. (2016), Comprehensive assessment and visualized monitoring of urban drinking water quality. - Chemometrics and Intelligent Laboratory Systems. 155, 26-35. 